Doutor e mestre em Literatura Comparada pelo Programa de Pós-Graduação em Ciência da Literatura da Universidade Federal do Rio de Janeiro (UFRJ). Professor do Departamento. de Português e Literaturas
em Língua Portuguesa do Colégio Pedro II - Campus Tijuca II.

http://orcid.org/0000-0002-2460-004

E-mail: daniel.moutinho@gmail.com

Recebido em: 15/2/2019.

Aprovado em: 2/5/2019.

$6 / 12 / 2019$

Endereço:

, 550 , Cidade Universitária, Rio de Janeiro, RJ, CEP: 21941-901

\section{Uso da fotografia em Nove noites, de Bernardo Carvalho, e Vou lá visitar pastores, de Ruy Duarte de Carvalho}

\author{
The use of photography in Nove noites, by Bernardo Carvalho, and \\ Vou lá visitar pastores, by Ruy Duarte de Carvalho
}

Daniel Moutinho Souza ${ }^{1}$

Universidade Federal do Rio de Janeiro, Programa de Pós-Graduação em Ciência da Literatura, Rio de Janeiro, RJ, Brasil.

\section{RESUMO}

Este artigo se baseia em formulações teóricas clássicas sobre a fotografia (Roland Barthes, Susan Sontag, Phillippe Dubois) com o objetivo de estudar comparativamente o uso da fotografia em duas obras contemporâneas. Em Nove noites (2002), o autor brasileiro Bernardo Carvalho inclui fotografias de alguns de seus personagens e de si próprio para sugerir uma relação problemática entre o enredo ficcional do romance e o "mundo real"; no ensaio Vou lá visitar pastores (2000), o antropólogo angolano Ruy Duarte de Carvalho faz o oposto: inclui em seu relato etnográfico fotografias tratadas de tal modo que a sua referência na realidade seja posta em questão, em consonância com o estilo de escrita que o aproxima do registro literário. Do fato de que a obra de Ruy Duarte foi comentada e elogiada por Bernardo Carvalho antes do surgimento de Nove noites deriva a hipótese de que a presença das fotografias nessas obras, com caráter ao mesmo tempo oposto e complementar, não seja uma coincidência.

Palavras-chave: Literatura Comparada. Fotografia. Ficção. Antropologia.

\section{ABSTRACT}

This article is based on classic theorizations on photography (Roland Barthes, Susan Sontag, Phillippe Dubois) aiming at a comparative study of the use of photography in two contemporary works. In Nove noites (2002), Brazilian author Bernardo Carvalho includes photographies of some of his characters and of himself to suggest a problematic relation between the fictional plot of the novel and the "real world"; in the essay Vou lá visitar pastores (2000), Angolan anthropologist Ruy Duarte de Carvalho does the opposite: includes in his ethnographic report photographies treated in such a way that their reference on reality is questioned, in agreement with the writing style which approximates him of literary language. From the fact that Ruy Duarte's work was positively commented by Bernardo Carvalho before the making of Nove noites comes the hypothesis that the presence of photographies in both works, with characteristics at the same time opposite e supplementary, is not a coincidence.

Keywords: Comparative Literature. Photography. Fiction. Anthropology. 
"Na década de 1920, o fotógrafo se tornara um herói moderno, como o aviador e o antropólogo - sem necessariamente ter saído de sua terra natal".

(Susan Sontag, Sobre fotografia)

\section{Introdução}

E

m 6 de janeiro de 2001, o jornalista e escritor Bernardo Carvalho escreveu, para o jornal Folha de S. Paulo, uma resenha crítica sobre o romance Os papéis do Inglês, do angolano Ruy Duarte de Carvalho². 0 texto, intitulado "A ficção hesitante", elogia a obra como "uma narrativa autorreflexiva das mais peculiares e originais" (CARVALHO, 2001) e comenta de passagem outro livro do mesmo autor, o relato etnológico Vou lá visitar pastores, escrito e publicado na mesma época3.

No ano seguinte, veio a público Nove noites, sexto romance do escritor paulista, sobre o qual é possível sugerir, como hipótese, influência da obra de Ruy Duarte. 0 enredo, por exemplo, é bastante semelhante ao de Os papéis do Inglês. Com relação a Vou lá visitar pastores, o contato mais evidente é o uso de fotografias como mais do que ilustrações, mas como parte significativa do conteúdo da obra.

0 propósito deste trabalho será comparar o emprego dessas fotografias nessas obras de objetivos distintos, mas que convergem em aspectos importantes. Para tanto, partiremos de formulações teóricas sobre a fotografia - principalmente $A$ câmara clara, de Roland Barthes (2012), Sobre fotografia, de Susan Sontag (2004), e $O$ ato fotográfico, de Phillippe Dubois (1994), para compreender o entrelaçamento entre as linguagens verbal e fotográfica nas obras referidas. Procuraremos demonstrar que, em Nove noites, a presença das fotografias "perturba" o universo ficcional ao sugerir uma presença da "realidade". Em Vou lá visitar pastores ocorre o inverso: trata-se de uma obra de cunho acadêmico-científico, ou seja, com lastro na observação do mundo do real, mas nela as fotografias não registram os personagens e os ambientes de modo objetivo, configurando um uso poético

CARVALHO, Ruy Duarte de. Os papéis do Inglês. Lisboa: Cotovia, 2000.

Edição portuguesa pela Cotovia (1999) e brasileira pela Gryphus (2000). também presente na escrita de Ruy Duarte de Carvalho. Em ambas as obras, portanto, a fotografia opera um entrelaçamento entre realidade e ambiente poético-ficcional de modos que podem ser vistos como complementares.

\section{As fotografias em Nove noites: retorno do passado}

A referência explícita da origem de Nove noites, de Bernardo Carvalho (2002), é o artigo "Paixão etnológica", escrito pela antropóloga Mariza Corrêa e publicado na Folha de S. Paulo, em 12 de maio de 20014. Esse texto menciona de passagem o suicídio do antropólogo norte-americano Buell Quain em 1939, quando estudava os índios krahô, próximo à divisa dos atuais estados do Maranhão e Tocantins. No romance, o narrador de Bernardo Carvalho começa a pesquisar a fundo sobre esse episódio, sem que ele mesmo compreenda o porquê de tal obsessão. Porém, passaram-se mais de 60 anos e muitas pistas se revelam frustrantes, insuficientes. Toda a obra é construída de maneira a manter indefinida a relação entre o que é histórico e o que é ficcional (estratégia mantida pelo autor em entrevistas e palestras sobre esse livro).

A exemplo de parte expressiva da ficção contemporânea, o sexto romance de Bernardo Carvalho conta, no mínimo, duas histórias. 0 seu ponto de partida é a morte do antropólogo norte-americano Buell Quain, que chegou ao Brasil em 1938 e, no ano seguinte, suicidou-se no percurso entre a tribo krahô e a cidade de Carolina (no estado do Maranhão, às margens do rio Tocantins). Por décadas esse episódio permaneceu de conhecimento quase restrito ao meio da Antropologia, até que o narrador se depara com uma menção a ele no artigo de Mariza Corrêa. 0 texto atiça a sua curiosidade - por motivos que o leitor, em grande parte, ignora -, e ele então inicia uma investigação em busca do que teria motivado o suicídio de Quain. Em outras palavras, segue os rastros, os vestígios, do antropólogo. Ao mesmo tempo, as suas descobertas o levam a um mergulho no próprio passado.

Esse narrador, que em momento algum é nomeado, é bisneto do marechal Rondon, frequentou a região do Xingu em parte de sua infância na década de 1960, mora em São Paulo, é jornalista, viveu certo período em Paris, onde

4 Disponível em: http://www1.folha.uol.com.br/fsp/resenha/rs1205200103.htm. Acesso em: 2 dez. 2016. 
entrevistou o antropólogo Claude Lévi-Strauss duas vezes. Todos esses dados, extraídos das páginas de Nove noites, coincidem com a biografia do escritor Bernardo Carvalho, que na época da escrita desta obra trabalhava na Folha de S. Paulo (da qual é colunista ainda hoje). Isto é, são mobilizados fatos e recursos estilísticos para fundir a imagem do narrador com a do autor empírico.

A origem em dois episódios historicamente verificáveis - a morte de Quain e a publicação do artigo de Corrêa - e a coincidência biográfica narrador-autor são os primeiros sinais da mistura entre os mundos do real e do ficcional, assim como as pesquisas em arquivos públicos e particulares, no Brasil e nos Estados Unidos. A linguagem direta do texto também contribui para provocar no leitor a sensação de que não está lendo um romance, e sim os resultados de pesquisas e entrevistas - ou seja, um relato, uma reportagem. Isso ocorre, principalmente, quando o narrador apresenta detalhes sobre a missão antropológica americana no Brasil e as entrevistas que realizou:

Quain chegou ao Brasil em fevereiro de 1938. Desembarcou no Rio de Janeiro às vésperas do Carnaval. Foi morar numa pensão na Lapa, reduto de todos os vícios, da malandragem e da prostituição. [...]

Seu retorno contrariado à capital [na época, o Rio de Janeiro] coincidiu com a chegada ao Brasil de um colega da Universidade Columbia, Charles Wagley, que vinha de navio para estudar os Tapirapé, e também com a passagem de Ruth Landes pela cidade - a jovem antropóloga de Nova York estava no país havia meses com o objetivo de estudar os negros e o candomblé da Bahia. Os três eram alunos diletos de Ruth Benedict, uma das principais representantes da corrente antropológica que ficou conhecida por associar Cultura e Personalidade [...] (CARVALHO, 2002, p. 16-17).

Aos oitenta e oito anos, Castro Faria é um homem lúcido, muito articulado e com uma memória às vezes melhor do que a minha, embora sujeita às distorções das impressões subjetivas, como a de qualquer um. Falou de Quain durante mais de uma hora, sem se cansar. No início, foi mais reticente. Não chegaram a ser amigos: "As minhas relações com ele sempre foram superficiais. Sempre me tratou muito bem. Não tivemos intimidade..." (CARVALHO, 2002, p. 32).
Mesmo quando faz intervenções subjetivas ("melhor do que a minha"), o modo discursivo predominante é jornalístico, sobretudo na apresentação da fala do entrevistado, reforçado pelo fato de que menciona personagens de existência comprovável.

Nove noites é composto de 19 capítulos, com narradores alternados. Um é aquele que se confunde com o autor Bernardo Carvalho (capítulos 2, 4, 5, 7 , 9, 11, 13, 15, 17 e 19); chamá-lo-emos "narrador-jornalista". Os demais capítulos consistem em nove cartas escritas por Manoel Perna, engenheiro de Carolina, no Maranhão, que teria sido confidente de Buell Quain em suas passagens pela cidade. Com frequência, o início de um capítulo retoma diretamente uma referência feita no final do capítulo anterior. Mas o elemento decisivo para a organicidade do romance é o próprio entrelaçamento de fatos pesquisados, anotados, lembrados e relatados pelos dois narradores.

As cartas de Perna não possuem a linguagem objetiva do narrador-jornalista. São endereçadas a um destinatário desconhecido, que estaria buscando informações sobre o antropólogo. Dessa forma, elas parecem se dirigir ao narrador-jornalista ou ao próprio leitor, o qual se vê convidado a colaborar na solução do mistério. A primeira dessas cartas abre o romance anunciando a impossibilidade de distinguir verdade e mentira, realidade e ficção - e serve de aviso:

Isto é para quando você vier. É preciso estar preparado. Alguém terá de preveni-lo. Vai entrar numa terra em que a verdade e a mentira não têm mais os sentidos que o trouxeram até aqui. Pergunte aos índios. Qualquer coisa. 0 que primeiro lhe passar pela cabeça. E amanhã, ao acordar, faça de novo a mesma pergunta. E depois de amanhã, mais uma vez. Sempre a mesma pergunta. E a cada dia receberá uma resposta diferente. A verdade está perdida entre todas as contradições e os disparates. Quando vier à procura do que o passado enterrou, é preciso saber que estará às portas de uma terra em que a memória não pode ser exumada, pois o segredo, sendo o único bem que se leva para o túmulo, é também a única herança que se deixa aos que ficam, como você e eu, à espera de um sentido, nem que seja pela suposição do mistério, para acabar morrendo de curiosidade. Virá escorado em fatos que até então terão lhe parecido incontestáveis (CARVALHO, 2002, p. 7). 
A frase inicial, "Isto é para quando você vier", funciona como um refrão: ela se repete em oito das nove cartas de M. Perna - a exceção é a sexta carta (capítulo 12). Assim, esse destinatário é postulado, reiterado, mas jamais revelado objetivamente - "você, seja lá quem for". Assim, os seus enunciados parecem se dirigir ao leitor, alertado desde o início de que um dos temas centrais da narrativa é a hesitação entre o mundo do real e a invenção ficcional. As questões da verdade, da realidade, e das inevitáveis mentiras e ficções que a complementam são reiteradas insistentemente:

Sei o que espera de mim. E o que deve estar pensando. Mas não me peça o que nunca me deram, o preto no branco, a hora certa. Terá que contar apenas com o imponderável e a precariedade do que agora lhe conto, assim como tive de contar com o relato dos índios e a incerteza das traduções do professor Pessoa" (CARVALHO, 2002, p. 8).

Perna também desconhece o destinatário, mas esse parece ser norteamericano:

Desde então eu o esperei, seja você quem for. Sabia que viria em busca do que era seu, a carta que ele lhe escrevera antes de se matar e que, por segurança, me desculpe, guardei comigo, desconfiado, já que não podia compreender o que ali estava escrito..." (CARVALHO, 2002, p. 12).

Ele imagina que a última remessa de correspondência recebida por Quain tenha levado notícias que provocaram o suicídio. "Dos envelopes fechados, aquele era o único cujo destinatário, até onde eu sabia, não era da família do dr. Buell nem tampouco outro antropólogo" (CARVALHO, 2002, p. 12-13). Por isso, ao reconhecer o mesmo nome em uma das cartas escritas por Quain antes da morte, guardou-a.

As cartas de que nós, leitores do romance, tomamos conhecimento, são escritas por Manoel Perna seis anos depois, quando ele "não pode mais esperar". Não se informa pelo que ele não pôde esperar, porém posteriormente se afirma que Manoel Perna morreu afogado em 1946 - data que coincide com seis anos passados do suicídio de Quain. Desse modo, a temporalidade também contribui para a verossimilhança, para a sensação de que se trata de "fatos reais". E neste aspecto reside a importância das fotografias incluídas no romance.
No quarto capítulo, a entrevista com o antropólogo Luiz de Castro Faria é apresentada por uma fotografia em que são identificados Castro Faria, Charles Wagley, Ruth Landes, Heloísa Alberto Torres, o célebre antropólogo francês Claude Lévi-Strauss, além de Raimundo Lopes e de Edson Carneiro. Wagley, Landes e Alberto Torres são mencionados outras vezes no romance: os primeiros eram integrantes do intercâmbio entre o Departamento de Antropologia da Universidade de Columbia e o Museu Nacional; a última era então diretora do Museu e responsável pela estada dos pesquisadores norte-americanos no Brasil. Raimundo Lopes e Edson Carneiro são etnólogos brasileiros, e essa é a única menção a seus nomes no romance. 0 texto informa apenas: "Hoje, estão todos mortos, à exceção de Castro Faria e Lévi-Strauss” (CARVALHO, 2002, p. 32).

Imagem 1 - Antropólogos brasileiros e norte-americanos com Lévi-Strauss

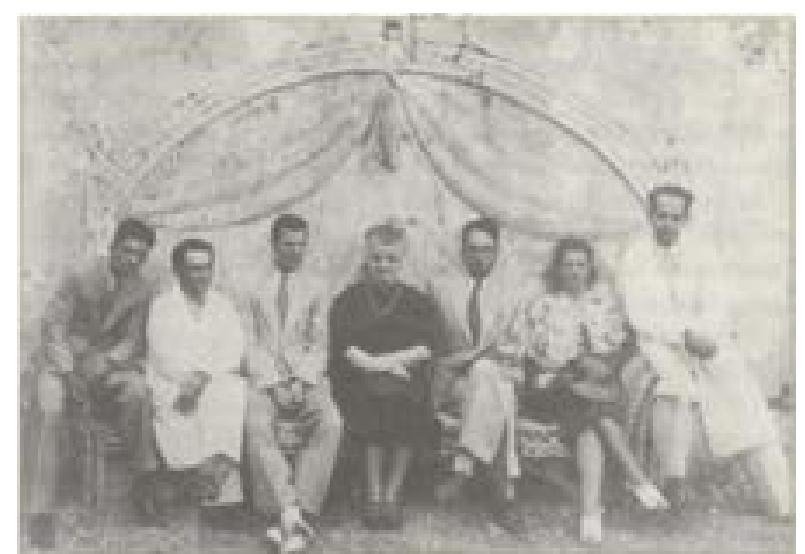

*Nota: Da esquerda para a direita: Edson Carneiro, Raimundo Lopes, Charles Wagley, Heloísa Alberto Torres, Claude Lévi-Strauss, Ruth Landes e Luiz de Castro Faria: antropólogos brasileiros e norte-americanos na passagem do francês Claude Lévi-Strauss no Rio de Janeiro.

Fonte: CARVALHO, 2002, p. 31.

Ao mesmo tempo em que estabelece uma relação "factual", supostamente objetiva, com o relato, essa fotografia revela o grau de envolvimento do narradorjornalista com sua pesquisa: "Na minha obsessão, cheguei a me flagrar várias vezes 
com a foto na mão, intrigado, vidrado, tentando em vão arrancar uma resposta dos olhos de Wagley, de dona Heloísa ou de Ruth Landes" (CARVALHO, 2002, p. 32).

Essa dinâmica de objetividade e subjetividade é essencial para compreender o emprego das fotografias em Nove noites. 0 leitor vê, além desta, as duas fotos com que Buell Quain presenteava as pessoas que conhecia no Brasil, em uma delas de frente, noutra de perfil, de camisa branca.

Imagem 2 - Fotos com que Buell Quain presenteava conhecidos
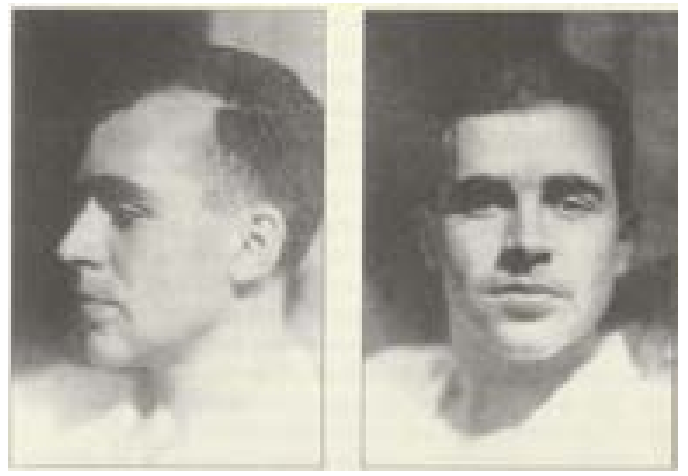

Fonte: CARVALHO, 2002, p. 26

Para Roland Barthes, as fotografias funcionam como "certificado de presença" (2012, p. 80), uma emanação do referente. 0 semiólogo francês descreveu a especificidade da fotografia, em relação a outras linguagens, pela expressão "Isso-foi" ("Ça a-été"):

Chamo de "referente fotográfico", não a coisa facultativamente real a que remete uma imagem ou um signo, mas a coisa necessariamente real que foi colocada diante da objetiva, sem a qual não haveria fotografia. A pintura pode simular a realidade sem tê-la visto. 0 discurso combina signos que certamente têm referentes, mas esses referentes podem ser e na maior parte das vezes são 'quimeras'. Ao contrário dessas imitações, na Fotografia jamais posso negar que a coisa esteve lá. Há dupla posição conjunta: de realidade e de passado. [...] a Referência, que é a ordem fundadora da Fotografia". [...] O nome do noema da Fotografia será então: 'Isso-foi', ou ainda: o Intratável (BARTHES, 2012, p. 72, grifo do autor).

A fórmula "Isso-foi" (Ça-a-été, no original) acompanhará toda a reflexão subsequente de Barthes; a foto será vista como "literalmente uma emanação do referente", como autenticação e ratificação, atestado de que "o que vejo de fato existiu" (BARTHES, 2012, p. 75) .

No romance de Bernardo Carvalho, elas sem dúvida participam do dispositivo de autentificação, ao trazer o mundo do real para o universo ficcional do romance. Ou, nos termos de Philippe Dubois, a relação indicial, de contiguidade física entre imagem e referente.

Dubois demonstra a existência, desde o advento dessa técnica, de três paradigmas teóricos sucessivos. Primeiramente, a fotografia foi vista como "espelho do real". Esse "discurso da mimese" surgiu no século XIX (com destaque para a crítica de Baudelaire em Salon de 1859), e permaneceu no século XX em alguns textos - notadamente, a "Ontologia da imagem fotográfica", de André Bazin (1945), e um primeiro Barthes, em "A imagem fotográfica" (1961).

O segundo paradigma é o da fotografia como "transformação do real (o discurso do código e da desconstrução)", predominante no período estruturalista e na crítica ideológica do signo fotográfico. Finalmente, o terceiro paradigma considera "a fotografia como traço de um real (o discurso do índice e da referência)" (DUBOIS, 1993, p. 45).

É interessante notar a mudança do artigo: anteriormente, tinha-se "espelho" e "transformação do real"; agora, "traço de um real". A realidade não é mais vista como una, e sim como mais dinâmica e diversificada, não passível de ser abarcada por uma imagem.

Para justificar esse conceito de "traço de um real", Dubois recorre à teoria dos signos de Charles Sanders Peirce. Peirce conceituou três tipos de signos: o ícone, caracterizado pela semelhança física em relação a seu referente; o símbolo, que detém com o significado uma relação convencional (como a linguagem verbal); e o índice, cuja identidade advém da relação de contiguidade física com o seu referente. Dubois demonstra que os primeiros paradigmas partiam do princípio de que a foto tem um "valor absoluto, ou pelo menos geral, seja por semelhança, seja por convenção" ((DUBOIS, 1993, p. 45, grifo do autor) - ou seja, o que para Peirce seriam "ícones" e "símbolos", respectivamente. 
E insiste: a especificidade da fotografia provém de seu caráter indicial: o conceito de índice tem como vantagem o fato de requerer uma "contiguidade física" entre a foto e o objeto retratado, de maneira que, mais do que uma "reprodução mimética" ou do que uma "emanação" do referente, a foto seja um objeto autônomo que depende da existência desse referente para existir.

A despeito da ênfase na referência (Barthes) ou no caráter indicial (Dubois), o fato é que as fotografias em Nove noites firmam os seus personagens no mundo do real.

A filósofa norte-americana Susan Sontag, por sua vez, recusa a ideia de uma emanação do real, conforme assinala o título do primeiro ensaio de seu livro Sobre fotografia, "Na caverna de Platão". A metáfora é clara: a fotografia não é uma forma confiável de conhecimento do mundo.

Sontag percebe que, "enquanto uma pintura ou uma descrição em prosa jamais podem ser outra coisa que não uma interpretação estritamente seletiva, pode-se tratar uma foto como uma transparência estritamente seletiva" (SONTAG, 2004, p. 16); eis a fotografia tratada como versão "transparente" do real, ressalvado o fato de que alguém escolheu produzi-la de uma ou outra maneira. Sontag (2004, p. 16) o nomeia "comércio usualmente nebuloso entre arte e verdade" e conclui: "Embora em certo sentido a câmera de fato capture a realidade, e não apenas a interprete, as fotos são uma interpretação do mundo tanto quanto as pinturas e os desenhos" (SONTAG, 2004, p. 17).

Entretanto as fotos de Quain exercem um outro efeito ainda. Segundo Susan Sontag,

a verdadeira diferença entre a aura que pode ter uma foto e a aura de uma pintura repousa na relação diferente com o tempo. [...] enquanto pinturas ou poemas não se tornam melhores, mais atraentes, apenas por envelhecer, todas as fotos são interessantes, além de comoventes, se forem velhas o bastante (SONTAG, 2004, p. 156-7).

É o que explica a fascinação corriqueira pelos antigos álbuns de família, sobretudo dos parentes já falecidos. O jornalista Eugênio Bucci, ao dissertar sobre uma foto de sua própria família, poeticamente analisa:
Em quase todas as fotos de quase todos os álbuns de quase todas as famílias, os fotografados encaram a câmera. Esse olhar tenta invadir o futuro, é um sintoma da expansão do presente [...], e também esconde uma súplica emudecida, dirigida aos que virão depois: 'Não me esqueçam quando eu já não estiver aqui'. Fotos de álbuns de famílias são inventários das faces dos mortos tentando adivinhar o próprio reflexo nos olhos de seus descendentes. Como as fotos três por quatro que a gente vê em algumas lápides, com rostos esmaecidos nos olhando sem piscar. As fotos antigas são lápides de cemitérios (BUCCI, 2008, p. 84).

É como se, na fórmula barthesiana, se ressaltasse menos a autentificação do "Isso", e mais o passado irrecuperável do tempo verbal, do "foi". Em outro trecho, Sontag avalia que

todas as fotos são memento mori. Tirar uma foto é participar da mortalidade, da vulnerabilidade e da mutabilidade de outra pessoa (ou coisa). Justamente por cortar uma fatia desse momento e congelá-la, toda foto testemunha a dissolução implacável do tempo (SONTAG, 2004, p. 26).

Em uma obra de ficção, esse efeito poderia ser atenuado; mas em Nove noites ele é inevitavelmente potente porque desde a primeira página se estabelecera a indissociabilidade entre mentira e verdade, entre universo da ficção e do real, e, sobretudo, porque o leitor recebe a foto de Quain logo depois de saber de seu suicídio brutal (e real), seis décadas antes da escrita do romance. Não há razão, nesse contexto, para duvidar da legitimidade das fotografias, no sentido de corresponderem exatamente ao que se diz delas e cumprirem uma função "documental".

Essa observação é ainda mais relevante no tocante à terceira fotografia, presente na orelha da primeira edição do livro, sobre a legenda: "O autor aos seis anos, no Xingu". A mesma foto estampa a capa de uma edição mais recente (2015), e não se encontra apenas na edição de bolso do romance (2006). Nela, o olhar do menino, intimidado pelo sol frontal, parece confuso, sem compreender o que se passa; a seu lado, um índio alto posa altivo, com postura e olhar confiantes. 0 contraste entre eles dificilmente poderia ser maior. 
Imagem 3 - Imagem na orelha da primeira edição

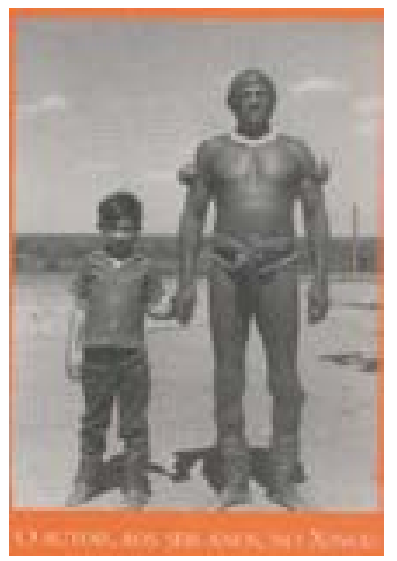

*Nota: Na orelha da primeira edição, a foto é acompanhada da legenda "O autor aos seis anos, no Xingu", acima de uma minibiografia de Carvalho Fonte: CARVALHO, 2002
Imagem 4 - Capa da edição de 2015

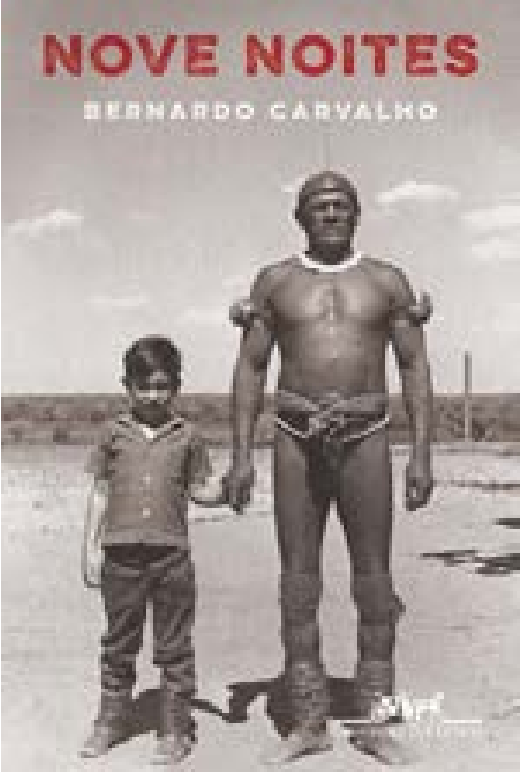

Se o primeiro terço do romance tratou de apresentar os fatos e algumas versões sobre a vida e a morte Buell Quain, no segundo terço (que corresponde ao longo capítulo 11) começam a ser esclarecidas as razões para a obsessão do narrador-jornalista em desvendar as causas do suicídio do antropólogo norte-americano. Após relatar o que descobriu sobre a missão da qual Quain era parte, ele passa a contar episódios de sua própria infância, quando era obrigado a acompanhar o pai em viagens ao Centro-Oeste brasileiro em pequenos aviões e condições precárias de segurança. "Ninguém nunca me perguntou, e por isso nunca precisei responder que a representação do inferno, tal como a imagino, também fica, ou ficava, no Xingu" (CARVALHO, 2002, p. 60).

Somos informados de que seu pai estava interessado em comprar fazendas no interior do Brasil, um bom negócio porque as terras eram baratas e o governo militar subsidiava projetos agropecuários com o objetivo de desenvolver a economia da região. Começam a surgir elementos de identificação entre o narrador e o antropólogo:

Buell Quain também havia acompanhado o pai em viagens de negócios [...] Mas se para Quain, que saía do Meio-Oeste para a civilização, o exótico foi logo associado a uma espécie de paraíso, à diferença e à possibilidade de escapar ao seu próprio meio e aos limites que haviam sido impostos por nascimento, para mim as viagens com o meu pai proporcionaram antes de mais nada uma visão e uma consciência do exótico como parte do inferno (CARVALHO, 2002, p. 64).

A interpretação leva a crer que essa experiência tenha contribuído para Quain tornar-se estudioso de culturas diversas, de ilhas no Pacífico ao interior do Brasil, enquanto, para o narrador, o romance soa como forma de purgar um trauma. De certa maneira, justifica-se a obsessão do narrador-jornalista - cuja identificação com o autor empírico foi reforçada pela fotografia no Xingu, em mais uma forma de simular a veracidade dos fatos narrados, de fundir os mundos exterior e interior à narração - pela vida e morte de Buell Quain, a ponto de ele contactar um casal de antropólogos de São Paulo para intermediar uma visita à aldeia krahô.

Àquela altura, eu já estava completamente obcecado, não conseguia pensar em outra coisa, e como todos os que eu havia procurado antes, eles 
também não quiseram saber por quê. Ninguém me perguntava a razão. Eu dizia que queria escrever um romance. Diante do meu entusiasmo, que a outros podia parecer doentio e inexplicável, acho que os dois de início ficaram apenas um pouco ressabiados (CARVALHO, 2002, p. 66).

Desde o início, quando indagado sobre o porquê de seu interesse pelo artigo de Mariza Corrêa, pelo suicídio de Quain, o narrador oferece essa mesma resposta: "queria escrever um romance". A literatura opera, aqui, como espécie de salvo-conduto, que justifica perguntas incômodas e uma relação tão pouco convencional com o objeto da pesquisa.

Quanto à obsessão, pode-se tratar de mais um recurso de ficcionalização; afinal, é traço característico da maioria dos protagonistas nos romances de Bernardo Carvalho - de modo central em obras como Teatro (1998), As iniciais (1999), O sol se põe em São Paulo (2007), Simpatia pelo Demônio (2016), mas de alguma maneira em toda a obra do escritor. E somente um personagem (ou um autor?) obsessivo chegaria ao final de uma busca ingrata e inglória pelos rastros de um antropólogo obscuro morto nos confins da selva há mais de 60 anos.

O capítulo 11, aquele em que o autorretrato do autor-narrador-jornalista é mais exposto, pode ser dividido em duas partes. Na primeira, conta-se o trauma deixado pelas viagens com o pai. Na segunda, a sua obsessão chega ao ápice: ele relata uma visita aos krahô, ao cenário do suicídio de Buell Quain, acompanhado do antropólogo paulista e do filho desse. A intenção é tentar encontrar, entrevistar alguém que tenha convivido com Quain em sua curta passagem pela cidade de Carolina e pela tribo.

Os índios o recebem com desconfiança, e o próprio narrador não disfarça seu desconforto físico e mental. Um jovem indígena o aborda perguntando por suas intenções:

Os velhos estavam preocupados, queriam saber por que eu vinha remexer no passado, e ele não gostava quando os velhos ficavam preocupados. Eu tentava convencê-lo de que não havia motivo para preocupação. Tudo o que eu queria saber já era conhecido. E ele me perguntava: 'Então, por que você quer saber, se já sabe?'. Tentei lhe explicar que pretendia escrever um livro e mais uma vez o que era um romance, o que era um livro de ficção (e mostrava o que tinha nas mãos), que seria tudo historinha, sem nenhuma consequência na realidade. Ele seguia incrédulo (CARVALHO, 2002, p. 85).
Como é típico do comportamento obsessivo, nem o próprio narrador consegue explicar as suas motivações, e evidentemente o salvo-conduto da literatura não é adequado para convencer o indígena, para quem o conceito de ficção soou incompreensível. Ainda assim, a pergunta do rapaz procede, e fica sem resposta: Por que investigar o que já se sabe? E por que é necessário pesquisar tão profundamente uma história verídica para escrever um texto de ficção?

0 terço final do livro também começa com uma aparente digressão relacionada ao pai do narrador-jornalista - como fora o longo capítulo em que fala dos episódios de sua infância no Xingu. Agora o pai está velho, falido e doente. 0 narrador e sua irmã conseguem uma vaga para ele em um hospital em São Paulo. Ao lado do leito do pai está um fotógrafo norte-americano, também idoso, o qual, em delírio, confunde o narrador com um certo "Bill Cohen", e vem a falecer após poucos dias. Passam-se alguns meses até a publicação do artigo da antropóloga Mariza Corrêa em que é mencionada a morte de Buell Quain, isto é, a narrativa reencontra o seu princípio. É o bastante para o obcecado narrador-jornalista entender que o norte-americano quisera dizer "Buell Quain”, e não Bill Cohen, e tê-lo como uma última chance de resgatar a história do etnólogo de Columbia. Ele obtém, então, um endereço em Nova York que seria do filho do fotógrafo. Esse se recusa a recebê-lo, mas o narrador parte mesmo assim.

A sequência final traz uma série de coincidências mais inverossímeis do que toda a improvável saga de Buell Quain. O narrador-jornalista encontra-se com Schlomo Parsons, filho do fotógrafo americano, no dia em que esse está de mudança de seu apartamento, ou seja, na última possibilidade de encontrá-lo no endereço conhecido. Após ter respondido que se recusaria a recebê-lo, Parsons atende o interfone e convida o narrador a subir. Ao saber que é brasileiro, exclama "Parece brincadeira! [...] Esse país me persegue" (CARVALHO, 2002, p.144) e mostra uma série de fotos de índios brasileiros, tiradas por seu pai - significativamente, essas não são incluídas no romance. Ao narrador-jornalista, parecem índios krahô; ele também pensa ver em seu anfitrião, por alguns instantes, traços fisionômicos de Buell Quain. No fim das contas, "não havia nada que provasse uma ligação entre Quain e o fotógrafo" (CARVALHO, 2002, p. 149).

As fotografias não provam nem comprovam nada. Mas a sua presença no romance passa pela insistência de Bernardo Carvalho em fincar os pés da narrativa o mais profundamente possível no mundo do real. Em nota ao final do livro, escreve o autor: "Este é um livro de ficção, embora esteja baseado 
em fatos, experiências e pessoas reais. É uma combinação de memória e imaginação - como todo romance, em maior ou menor grau, de forma mais ou menos direta" (CARVALHO, 2002, p. 169, grifo nosso). Ele então cita diversos nomes, aos quais agradece, e cuja presença percebemos ao longo da leitura de modo mais ou menos direto. Mas o que chama atenção é a ênfase no fato de que "todo romance" combina memória e imaginação. Qual o grau de cada um em Nove noites é outra questão que fica a critério de cada leitor.

Em suas palestras e entrevistas sobre Nove noites, Bernardo Carvalho sempre evitou fornecer pistas para possíveis leitores-detetives: "Eu não deveria dar entrevista. Tudo o que eu disser pode ser usado contra a minha ficção", ele disse a Cassiano Elek Machado na Folha de S. Paulo de 28 de setembro de 2002. Em entrevista à revista Trópico, o autor contou:

não vejo sentido em dizer o que é real e o que não é. [...] mesmo as partes em que elas [pessoas reais] aparecem podem ter sido inventadas. Em última instância, é tudo ficção.

Quando eu mostrei o livro à editora, eles ficaram apreensivos com a possibilidade de alguém me processar. Então consultaram um advogado. Ele leu o livro e disse que apenas uma pessoa poderia entrar na justiça contra mim. Mas esse perigo eu não corria, porque, de todas as que ele analisou, aquela era a única que tinha sido inventada. Foi aí que percebi que o livro estava funcionando como ficção (CARVALHO, [2002 ou 2003]).

O dispositivo de Nove noites pode ser descrito, pois, como uma fusão da capacidade da fotografia de sugerir o mundo do real, sugestão essa amplificada pelo fato de os fatos narrados partirem de aspectos historicamente verificáveis, e então usar a "ficcionalidade" para demolir as barreiras entre documento e invenção - em certo sentido, entre mimesis e poiesis. 0 leitor, então, espera uma obra de ficção (um romance) e se depara com um emaranhado de informações indiscerníveis do mundo do real e, por conseguinte, irreconhecíveis como "apenas ficção".

\section{Fotografia e "meia-ficção" em Vou lá visitar pastores}

Vou lá visitar pastores é um relato etnográfico, indexado como "Descrições e viagens" e "Pastores nômades - Angola, Sul - Usos e costumes”. Assim se inicia:
Em Agosto de 1997 fiz mais uma ronda pela Província do Namibe, sudoeste de Angola, onde desde 1992 mantenho contacto frequente com alguns pastores kuvale. Estava previsto acompanhar-me, para se inteirar da terra e das gentes, e olhar para Angola a partir dali, um amigo meu, fixado em Londres e repórter da BBC. Acabei por fazer a viagem sem ele. Tardava e eu não podia adiar a partida. Admiti no entanto que talvez pudesse chegar ainda nos próximos dias, a tempo de alcançar-me. Fui-lhe por isso deixando cassetes com a gravação do que contava dizer-lhe pelo caminho. Era a maneira de tentar ajudá-lo, mesmo assim, a alargar o contacto com o que buscava. Não chegou a aparecer e mais tarde transcrevi essas cassetes. Divulgo agora os salvados, são a viagem do texto (CARVALHO, 2000, p. 11, grifo do autor).

A essa introdução Bernardo Carvalho referiu-se, na resenha "A ficção hesitante", como "uma epígrafe romanesca por excelência" (CARVALHO, 2001). A exemplo do "Isto é para quando você vier" das cartas de Manoel Perna, o destinatário dessas fitas cassete é alguém que nunca vem, e assim fica sendo uma função retórica, estendida ao próprio leitor. Essa interferência de recursos e linguagem literária em obra a priori não ficcional é traço importante da poética de Ruy Duarte de Carvalho. A esse respeito, a pesquisadora Laura Regina Dela Valle (2015, p. 12) utiliza o verbo "transumar", geralmente reservado à migração de povos nômades como os kuvale, para se referir às transições discursivas do autor - "a transumar pelos espaços e pelos discursos" -, e registra a expressão "híbrido romancista-etnógrafo" escolhida por Laura Cavalcante Padilha (2012 apud DELA VALLE, 2015, p. 19).

0 próprio autor reforçou essa concepção. Em um texto intitulado "Uma espécie de habilidade autobiográfica", ele menciona "uma meia-ficção em que venho insistindo nos últimos anos" (CARVALHO, 2010). De acordo com Laura Dela Valle (2015, p. 18), em dissertação de mestrado sobre a obra de Ruy Duarte de Carvalho, esse texto foi escrito para o Jornal de Letras e esteve no website da editora portuguesa Cotovia, de onde foi republicado nos portais Buala (na íntegra) e Esquerda.net (fragmentos) por ocasião da morte do escritor, em 2010. Porém, curiosamente, essas duas versões apresentam algumas diferenças; na versão do Esquerda Net, essa expressão ocorre como "meia-ficção-erudito-poético-viajeira". Como o texto foi retirado da página da Cotovia, é difícil saber qual é a versão oficial, ou definitiva5.

ESQUERDA.NET. "Morreu o escritor Ruy Duarte de Carvalho". Disponível em www.esquerda.net/artigo/ morreu-o-escritor-ruy-duarte-de-carvalho. Acesso em 23.out.2018. 
De todo modo, Vou lá visitar pastores impõe-se como relato etnográfico, mas estrutura-se e lê-se como se fosse um romance de viagem, com um narrador especializado que descreve o modo de vida dos kuvale ao mesmo tempo em que avança em sua nova exploração da região. Esse caráter romanesco e subjetivo é anunciado desde o título, não apenas pelo emprego da primeira pessoa, como também pela escolha do verbo "visitar", que supõe uma relação amigável, informal - de modo a deliberadamente fundir as enunciações literária e a científica. 0 texto é dividido em quatro partes, cada uma delas subdividida em capítulos que correspondem, cada um, a uma fita cassete gravada pelo narrador-antropólogo para o amigo. Assim se conclui a primeira parte:

É madrugada e vou agora tentar dormir um pouco. Dentro de poucas horas estarei a voar para o Namibe, onde poderás eventualmente vir a encontrar-me munido da matéria que te lego nestas quatro cassetes. E no entanto, e à semelhança do que me tem acontecido de todas as vezes em que me exponho, exponho o que sei sobre os Mucubais, ela fica muito aquém do que me ocorreria revelar de uma única e definitiva vez (CARVALHO, 2000, p. 98).

O fragmento reúne os três traços apresentados sobre a prosa de Ruy Duarte: a interferência de uma voz em primeira pessoa que se confunde com a do próprio autor; o seu conhecimento e seu trabalho antropológico e etnológico; e a presença dessa segunda pessoa, um destinatário postulado e instalado no texto, de maneira que literatura e antropologia se tornam interconectados e indiscerníveis: "A parte norte do território kuvale é de alguma forma excêntrica em relação à incidência maior do meu inquérito e das minhas experiências, tanto a recente quanto a remota, da infância" (CARVALHO, 2000, p. 75).

Na segunda parte, em um árido capítulo com descrições técnicas da topografia e da vegetação do Namibe, em uma tentativa de responder por que as populações kuvale teriam escolhido uma região tão hostil, o narrador comenta: "Eis uma nova rampa de lançamento para a imaginação mórbida do poeta que não dá folga ao antropólogo" (CARVALHO, 2000, p. 121). Mais adiante, referindo-se às migrações desses povos pelo território do Namibe:
Os do Xingo vão dar encontro no Mulovei com os do Kamukuio e do Tyinkite, enquanto os do Kavelokamo, Virei, Tyitundu-Hulu vão dar encontro com os do Hakahona, outros demandam o Virulundo, do lado do Kuroka. Fico por aqui porque me estou a deixar arrastar pela música da toponímia" (CARVALHO, 2000, p. 273).

Ficam nítidas a impossibilidade e a recusa de separar o poeta do antropólogo, o tema de suas teses científicas de uma experiência pessoal e de linguagem. Daí sua conclusão, após comentar os desafios da comunidade kuvale dentro do contexto social e político na Angola contemporânea: "Não é só a salvação dos Kuvale que está em causa, é a minha também..." (CARVALHO, 2000, p. 375).

Acresce que todo este livro é permeado por 55 "registros fotográficos do autor". Essas fotos, porém, dificilmente poderiam ser comparadas às imagens que ajudaram Bernardo Carvalho a compor Nove noites.

Imagem 5 - Homem kuvale

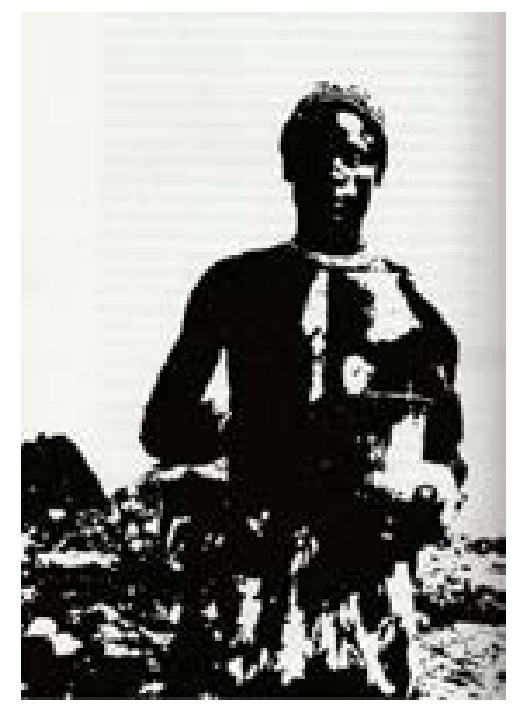

Fonte: CARVALHO, 2000, p. 132 
Imagem 6 - Boi kuvale

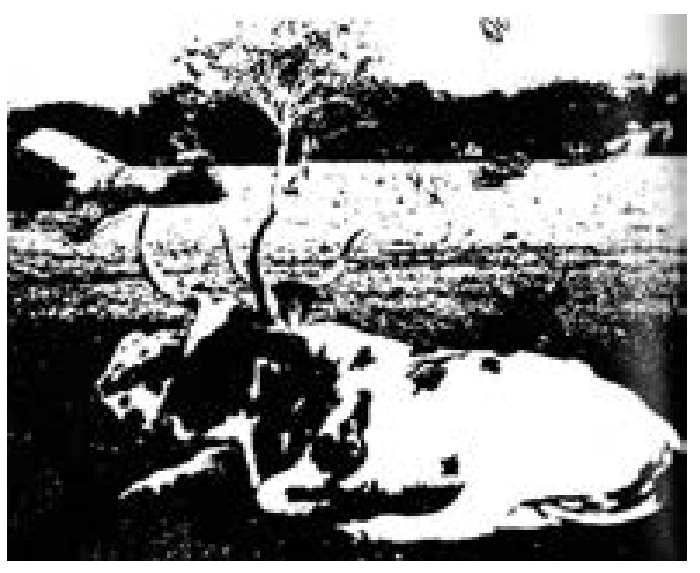

Fonte: CARVALHO, 2000, p. 306

No romance de Bernardo Carvalho, as fotografias exerciam a função de trazer para o discurso ficcional a presença "autentificada" do real, transmitindo aos personagens a presença concreta e a relação com a realidade compartilhada (a existência histórica de Claude Lévi-Strauss e outras personalidades conhecidas); aqui, o processo é reverso: se o livro é, de origem, um relato científico, etnográfico, essas imagens fotográficas escancaram uma intervenção da linguagem poética e subjetiva para ilustrar algo que é, que existe concretamente no deserto angolano.

Todas as fotografias são tratadas em laboratório de maneira a eliminar os tons de cinza, resultando em uma imagem mais sugestiva do que um retrato "objetivo". Mais do que ilustrar os fatos e as interpretações apresentadas pelo texto verbal, tornando-as mais convincentes, mais críveis ou de mais fácil assimilação, tais fotografias pertencem mais ao caráter inventivo, poético, que permeia a escrita do relato.

Neste caso, certamente não se enfatiza o Referente ("Isso-foi", tampouco "Isso-é") de Roland Barthes; nem o memento mori proposto por Susan Sontag; das vertentes teóricas apresentadas, apenas o caráter indicial assinalado por Dubois mantém a sua força, dado que o índice é um signo que, de fato, faz lembrar o ser que lhe deu origem e forma, não se confundindo com ele.
Imagem 7 - Aldeia kuvale

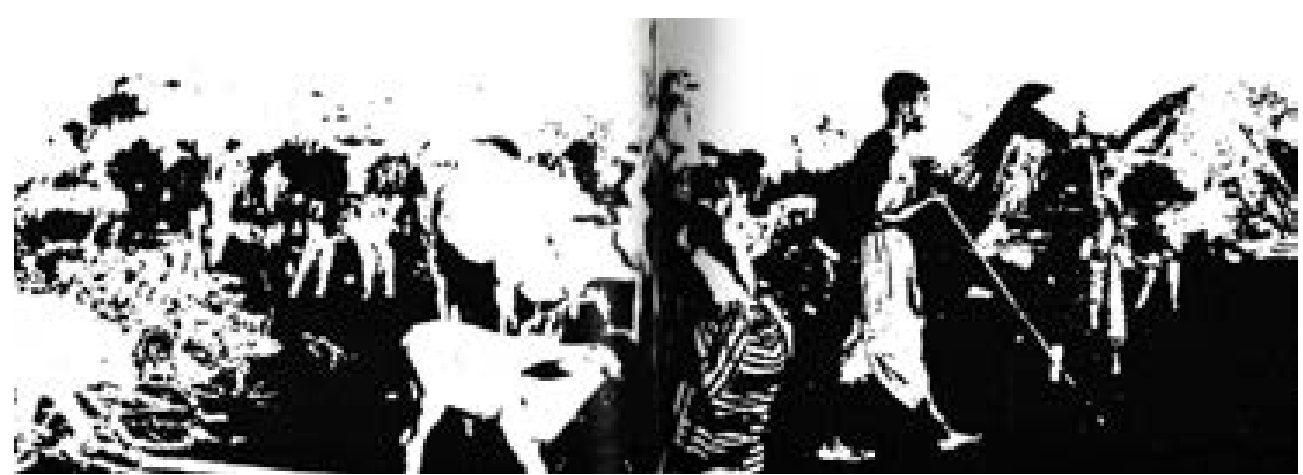

Fonte: CARVALHO, 2000, p. 184-185.

O entrelugar discursivo de onde Ruy Duarte escreve é mais uma vez escancarado: na abertura do livro, ele cita "registros fotográficos", no entanto o emprego das fotografias está longe de funcionar como "registro"; ele se aproxima de um uso estético, de uma linguagem indireta e sugestiva, cuja expressão verbal se pode encontrar em uma das mais belas passagens do relato, quando o narrador-antropólogo explica as razões de sua viagem pelo Namibe:

De repente vês-te situado com grande nitidez e precisão no ponto exacto a que os teus percursos te conduziram, imobilizado, por assim dizer suspenso, nalguma simples curva do caminho que a vida e tu próprio urdiram, retido num momento, num tempo, que nem os programas nem as agendas previam mas que ocorre assim sem pedir licença, um simples acidente de percurso que ao impor-se, no entanto, acaba por marcar uma cisão de idades. Que a ficção aproveita e utiliza tais momentos, quem lê ou escreve reconhece o método. É quando normalmente ocorrem os flash-backs, e os diálogos interiores emergem e revolvem toda a trama do enredo. E nas mãos dos grandes mestres o enredo é afinal só esse, é nesse mosto espesso que se desenvolvem as temperaturas extremas das fermentações da alma e das destilações do espírito, dos desdobramentos do querer e da consumação das metamorfoses do ser. E quem não escreve nem lê também há-de saber disso porque afinal julgo que não há quem não sinta, embora não lhe ocorra obrigatoriamente referi-lo porque isso será 
mais uma vez uma questão de enquadramento e de colocação cultural, que a sua vida daria um romance, ela é um caso, é o resumo do mundo e o mundo, sem remédio, sou eu no centro e o resto é à volta. 0 que será talvez dizer, sem querer e nem poder ir muito mais além, que não haverá quem não se confronte, quando tal ocorre e à sua maneira, com o curso da sua própria existência, e ao fazê-lo o transforma em discurso. Para uso próprio a maioria das vezes, mas de qualquer forma marcado por tempos, por ritmos, projecções, 'arrêts sur image', acelerados, fundidos, um filme, enfim. A consciência, julgo, faz-se de memória, de identificação de factores, de retenção de conceitos, arrumações, ponderações, conjecturas e avaliação de probabilidades, e esse é um dado universal, inerente à condição de pessoa, parece-me. Não haverá assim quem não seja operador de ficções e a realidade, essa, esvai-se, ficou mais é a experiência, inscreveu-se a estória. Direi, amanhã, ou não direi, rezarei só para mim, é mais o que retive, não o que vivi (CARVALHO, 2000, p. 105-106, grifo do autor).

A página de Ruy Carvalho sobrepõe trajetória individual e pesquisa (acadêmica), entre ficção pessoal ("minha vida daria um romance") e experiência concreta do ser (toda vida poderia ser um documentário), entre linguagem e fato, de um modo que pode também descrever a posição do narrador-jornalista de Nove noites.

\section{Considerações finais}

A obra do antropólogo angolano Ruy Duarte de Carvalho apresenta uma linguagem inovadora, em que objetivos científicos são fundidos com experimentações formais e recursos típicos do discurso ficcional. Nesse sentido, desaparece de seu texto a hierarquia entre o recurso literário e o conteúdo acadêmico, servindo sempre um de apoio ao outro. Percebe-se que o autor não reconhece fronteiras - seu trabalho de campo como antropólogo é também uma plataforma para pesquisas linguísticas, e o seu trabalho como poeta e ficcionista serve-se de seus conhecimentos profissionais.

Uma das formas de expressão desse entrelugar é a maneira como se constrói o relato etnográfico Vou lá visitar pastores. O leitor, ao mesmo tempo em que acompanha a viagem do narrador, coloca-se no lugar do destinatário ausente, e assim se sente convidado não apenas a ler uma obra científica, mas a fazer parte dela de um ponto de vista inusitado. As fotografias constituem uma parte importante dessa estratégia. Devido ao seu caráter indicial, da impossibilidade de separá-las da presença física do referente, contribuem para aproximar o leitor do universo retratado; ao mesmo tempo, pelo fato de elas estarem tratadas de modo a eliminar os tons de cinza, não dão acesso ao conhecimento supostamente "direto" que se esperaria de fotografias presentes em um estudo científico. Por elas somos lembrados da poeticidade que Ruy Carvalho não consegue dissociar de sua escrita acadêmica.

Bernardo Carvalho, por sua vez, faz um uso diferente das fotografias no romance Nove noites. Neste, o autor quer que o leitor reconheça a imagem de seus personagens de modo objetivo. 0 fator inquietante, aqui, é que as fotos (do grupo de antropólogos no Museu Nacional, de Buell Quain, no próprio autor ao lado de um indígena no Xingu) trazem a presença do mundo do real para dentro de uma obra ficcional. Desta maneira, elas sem dúvida fazem parte do esforço, presente ao longo de todo o romance, de confundir deliberadamente pesquisa e invenção, fato e ficção.

Em outras palavras, em ambas as obras analisadas as fotografias ajudam a quebrar toda forma de hierarquia entre o mundo do real e o universo ficcional. Em Vou lá visitar pastores, elas são recurso poético dentro de relato acadêmicocientífico; em Nove noites, ao contrário, marcam a presença da realidade na obra de invenção ficcional.

Quando se tem em mente que, na escrita de seu romance, Bernardo Carvalho tinha notícia da obra de Ruy Duarte de Carvalho, a qual elogiou em resenha publicada, ${ }^{6}$ e se tinha deixado influenciar por ele - as aproximações entre os enredos de Os papéis do Inglês e Nove noites são nítidas -, então, esse diálogo entre os dois, se torna ainda mais produtivo.
CARVALHO, Bernardo. "A ficção hesitante". Folha de S.Paulo, 06.jan.2001. Disponível em http://www1. folha.uol.com.br/fsp/ilustrad/fq0601200113.htm. Acesso em 01.abr.2018. 


\section{Referências}

BARTHES, Roland. A câmara clara. Tradução de Júlio Castañon Guimarães. Rio de Janeiro: Nova Fronteira, 2012.

BUCCI, Eugênio. Meu pai, meus irmãos e o tempo. In: MAMMI, Lorenzo; SCHWARZ, Lilia Moritz (org.). 8 x Fotografia. São Paulo: Companhia das Letras, 2008.

CARVALHO, Bernardo. Nove noites. São Paulo: Companhia das Letras, 2002.

CARVALHO, Bernardo. A trama traiçoeira de Nove noites. Entrevista concedida a Flávio Moura. Revista Trópico, s/d. Disponível em: http://p.php.uol.com.br/tropico/html/textos/1586,1.shl. Acesso em: 28.ago. 2019.

CARVALHO, Bernardo. A ficção hesitante. Folha de S.Paulo, São Paulo, 06 jan. 2001. Disponível em: http://www1.folha.uol.com.br/fsp/ilustrad/fq0601200113.htm. Acesso em: 01abr. 2018.

CARVALHO, Ruy Duarte de. Vou lá visitar pastores. Rio de Janeiro: Gryphus, 2000.

CARVALHO, Ruy Duarte de. Uuma espécie de habilidade autobiográfica. BUALA, 12. ago. 2010. Disponível em: http://www.buala.org/pt/ruy-duarte-de-carvalho/uma-especie-de-habilidadeautobiografica. Acesso em: 23 out. 2018.

CORRÊA, Mariza. Paixão etnológica. Folha de S.Paulo, 12 maio 2001. Disponível em http:// www1.folha.uol.com.br/fsp/resenha/rs1205200103.htm. Acesso em: 13 fev. 2019.

DELA VALLE, Laura Regina dos Santos. O Espaço vivido: Literatura e antropologia em Ruy Duarte de Carvalho. 2015. Dissertação (Mestrado em Literatura Brasileira e Luso-Africanas Instituto de Letras, Universidade Federal do Rio Grande do Sul, Porto Alegre.

DUBOIS, Philippe. $O$ ato fotográfico e outros ensaios. Tradução de Marina Appenzeller. Campinas: Papirus, 1994.

ESQUERDA.NET. Morreu o escritor Ruy Duarte de Carvalho. Disponível em www.esquerda. net/artigo/morreu-o-escritor-ruy-duarte-de-carvalho. Acesso em: 23 out 2018.

SONTAG, Susan. Sobre fotografia. Tradução de Rubens Figueiredo. São Paulo: Companhia das Letras, 2004. 